\title{
СОЧЕТАНИЕ БИОЛОГИЧЕСКОГО ПРЕПАРАТА НА ОСНОВЕ БАКТЕРИЙ PSEUDOMONAS FLUORESCENS И СТИМУЛИРУЮЩИХ ВЕЩЕСТВ.
}

\author{
Соломийчук ${ }^{1}$ М.П. , Панимарчук² О.И., Кушнір ${ }^{3}$ В.М.,Никорюк ${ }^{1}$ М.Г. \\ ${ }^{1}$ Украинская научно-исследовательская станция карантина растений ИЗР НААН, г. \\ Черновиьл, Украина, \\ ${ }^{2}$ Буковинский государственный медицинский университет. г. Черновиьь, Украина \\ ${ }^{3}$ Черновицкий наџиональный университет, г. Черновцы, Украина, \\ E-mail: ukrndskr@gmail.com
}

\begin{abstract}
Derivatives of ammonium salts of dihydropyrimidine did not show a toxic effect on reducing the concentration of viable cells of the bacterium strain AR-33 Pseudomonas fluorescens. The best indicators of the weight of 100 seeds and the number of formed beans in soybeans were shown by the combination Planriz $-51 /$ ha $+0.1 \%$ solution of xymedon $+0.2 \%$ solution of succinic acid $+2 \mathrm{ml}$ of DMAE $+2 \mathrm{ml}$ of DMSO. The use of all combinations of biocomplexes showed the effectiveness of drugs against diseases in the range of 59.31-69.63\%. As a result of the use of biocomplexes, their fungicidal, immunoprotective and stimulating action, an increase in yield of $1.15-1.7$ times relative to control was recorded. The best yield on potatoes showed a combination of Planriz, v.s. (bacteria of strain AP-33 Pseudomonas fluorescens, 3x109 CFU / cm3) - $51 /$ ha $+0.1 \%$ solution of ximedon + $0.2 \%$ solution of succinic acid $+2 \mathrm{ml}$ of DMAE $+2 \mathrm{ml}$ of DMSO, which was $3,4 \mathrm{t} /$ ha. The effectiveness of the drug against late blight was $79.1 \%$.
\end{abstract}

Key words: biological agents, pests, biological preparation, stimulant.

\section{Введение}

Для защиты растений широко применяются бактериальные препараты на основе псевдомонад спектр действия которого достаточно широк: на зерновых против корневых гнилей, помидорах и огурцах против бактериоза, фузариозу, вертицилезу, 
риктониозу, корневых гнилей, на капусте против черной ножки, бактериозов; в саду против парши. Бактерии хорошо усваивают различные органические субстраты, скорее других микроорганизмов колонизируют всю корневую систему, продуцируют антибиотики и сидерофоры, подавляя развитие фитопатогенных грибов. Важным аспектом в применении биологических препаратов является их возможность сочетаний с веществами стимулирующего действия для повышения вегетационных показателей растений и увеличения конкурентоспособности с химическими средствами защиты.

В сотрудничестве с Черновицким национальным университетом им. Ю. Федьковича проведена работа по синтезу и испытанию безопасных синтетических антиоксидантов на примере патиогенних производных метоксикарбонилдигидропиримидину и определения их биологической активности при защите растений на основе бактерий Pseudomonas fluorenscens. Катиогенни производные метоксикарбонилдигидропиримидину в низких концентрациях оказывают достаточно высокую антиоксидантным свойством. Данные вещества мало токсичным, что дает возможность исследовать их использования в совокупности с биологическими препаратами. В течение двух последних десятилетий производные 3,4дигидропиримидины-2 (1H) -ону привлекают внимание исследователей как системы с выраженным комплексом стимулирующей и антиоксидантной активности.

В связи с увеличением спроса на продукцию органического земледелия возникает потребность в изучении и внедрении технологий, обеспечивающих получение экологически чистой сельхозпродукции без применения химических средств защиты, генмодифицированных организмов, и с минимальной обработкой почвы, а также повышения активности биологических препаратов в баковых смесях и новых препаратах.

\section{Материалы и методы}

Для исследований использовались бактериии штама AP-33 Pseudomonas fluorescens, с титром в рамках $3 \times 10^{9} \mathrm{KOE} / \mathrm{cm}^{3}$.

Целевые объекты:

1. Соя, плесени, аскохитоз, фузариоз.

2. Картофель, фитофтороз.

Как стимулирующие вещества использовались:

- $\quad$ янтарная кислота - этан-1,2дикарбонова кислота НОOC (CH2) 2COOH бесцветный кристаллический порошок, влияет на активность микрофлоры почвы. Кислота содержит 99,72\% основного вещества, 0,0001\% - фосфатов, 0,00044\% - железа, 0,0076\% - оксида серы и 0,00082\% хлора;

- производные группы аммонийных солей дигидропиримидину, которые включают в шестом положении цикла четвертичное аммонийного группировки и отличаются природой заместителя в четвёртом положении (амін 1, амін 2, амін 3);

- соединения дигидропиримидины синтезированные на основе реакции циклоконденсации Биджинелли;

• $\quad$ ксемидон - гидроксиетилдиметилдигидропиримидин.<smiles>CCOC(=O)C1=C(C[N+](C)(C)Br)NC(=O)NC1[Al]</smiles><smiles>Cc1cc(C)n(CCO)c(=O)n1</smiles> 
Производные группы аммонийных солей

дигидропиримидина
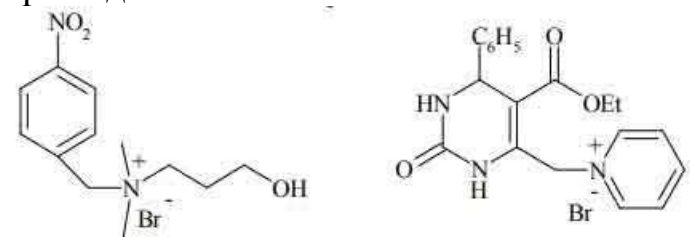

Соединения дигидропиримидина синтезированные на основе реакции циклоконденсации Биджинелли

Вспомогательнье вещества:

- ДМАЭ - диметиламиноэтанол. Использование DMAE в качестве иммунопротектора, который влияет на различные трансмембранные функции.

- Диметилсульфоксид (ДМСО) - Важный биполярные апротонный растворитель. Обеспечивает растворение органичных веществ и проникновение их сквозь мембраны.

\section{Результаты и обсуждение}

Для анализа возможного токсического воздействия группы аммонийных солей дигидропиримидину, стимуляторов и вспомогательных веществ на состояние бактерии Pseudomonas fluorescens, определяли концентрацию жизнеспособных клеток, с внесением веществ в готовый препарат.

По результатам исследований отмечено, что концентрация жизнеспособных клеток бактерий Pseudomonas fluorescens в приготовленных продуктах в рекомендованных концентраций не приводили к снижению их концентрации ниже норм (табл. 1). Однако следует отметить, что некоторые комбинации показали снижение титра жизнеспособных клеток в препарате по сравнению с контролем.

Исследование эффективности различных сочетаний в комплексах обработки сои показало, что использование почти всех комбинаций привело к повышению ряда вегетационных и физиологических показателей в разной степени. При применении планриз, 5,0 л/га + янтарная кислота отмечено повышение количества сформированных бобов в 1,4 раза относительно контроля. Показатели массы 100 семян при применении планриз,. 5,0 л/га + p-н ксимедону превышал контроль 1,6 раза и был выше комбинации с янтарной кислотой. Следует отметить, что лучшие показатели массы 100 семян и количества сформированных бобов показало сочетание планриз, 5 л/га $+0,1 \%$ раствор ксимедону $+0,2 \%$ раствор янтарной кислоты +2 мл ДМАЭ + 2 мл ДМSO.

Использование всех комбинаций биокомплексов показало эффективность препаратов против болезней в пределах 59,31- 69,63\%. В результате использования биокомплексов, их фунгицидные, имунопротекторний и стимулирующему действию, зафиксировано повышение урожайности в 1,15 - 1,7 раза относительно контроля. Лучший результат показал планриз, 5 л/га + 0,1 \% раствор ксимедону $+0,2 \%$ раствор янтарной кислоты + 2 мл ДМАЭ + 2 мл ДМSO, что составляло 3,4 т/га.

Использование ДМАЭ и ДМSO, как веществ, что имеют влияние на различные трансмембранные функции, обеспечило увеличение эффективности препаратов на 8-12 \% относительно комбинаций без их использования.

Аналогичную картину наблюдали и на опытах по изучению эффективности действия препаратов на основе бактерий Pseudomonas fluorescens в сочетании с веществами группы аммонийных солей дигидропиримидину, веществ стимулирующей природы на картофеле. Использование комбинаций обеспечивало увеличение 
семенной фракции при уборке картофеля. Также обеспечило увеличение урожая в 1,7 раза относительно контроля при применении комплекса планриз, 5 л/га $+0,1 \%$ раствор ксимедону $+0,2 \%$ раствор янтарной кислоты +2 мл ДМАЭ + 2 мл ДМSO.

Таблица 1

Влияние препаратов группы аммонийных солей дигидропиримидину в сочетании с веществами стимулирующей природы на титр препарата при наработке бактерий Pseudomonas fluorescens

\begin{tabular}{|c|c|c|c|}
\hline \multirow[t]{2}{*}{ варианты } & \multicolumn{3}{|c|}{$\begin{array}{c}\text { Концентрация } \\
\text { жизнеспособных клеток в } \\
\text { препарате } \\
\left(10^{9} \text { клеток / см }{ }^{3}\right), \\
\text { на день }\end{array}$} \\
\hline & 5 & 10 & 15 \\
\hline Pseudomonas fluorescens $-5 \mathrm{\pi} / \mathrm{ra}$ & 3,06 & 3,02 & 3,01 \\
\hline $\begin{array}{l}\text { Pseudomonas fluorescens, }-5 \text { л/га }+2 \text { мл ДМАЕ }+2 \text { мл } \\
\text { ДMSO }\end{array}$ & 3,1 & 3,04 & 3,01 \\
\hline $\begin{array}{l}\text { Pseudomonas fluorescens - } 5 \text { л/га }+ \text { Сполуки Біджінелі } \\
0,00025 \% \text {; }\end{array}$ & 2,93 & 2,81 & 2,66 \\
\hline $\begin{array}{l}\text { Pseudomonas fluorescens, }-5 \text { л/га }+0,2 \% \text { р-р янтарной } \\
\text { кислоты }+2 \text { мл ДМАЕ }+2 \text { мл ДМSО }\end{array}$ & 3,07 & 3,03 & 2,96 \\
\hline $\begin{array}{l}\text { Pseudomonas fluorescens,- } 5 \text { л/га производные } \\
\text { дигидропиримидина (амин } 1-0,5 \% \text { p-p + } 2 \text { мл ДМSO } \\
\text { ); }\end{array}$ & 3,08 & 2,96 & 2,85 \\
\hline $\begin{array}{l}\text { Pseudomonas fluorescens, }-5 \text { л/га }+ \text { производные } \\
\text { дигидропиримидина (амин } 2-0,25 \% \text { р-р }+2 \text { мл } \\
\text { ДМSO ); }\end{array}$ & 2,90 & 2,75 & 2,52 \\
\hline $\begin{array}{l}\text { Pseudomonas fluorescens,- } 5 \text { л/га + производные } \\
\text { дигидропиримидина (амин } 3-0,05 \% \text { р-р }+2 \text { мл } \\
\text { ДМSO); }\end{array}$ & 2,91 & 2,82 & 2,64 \\
\hline $\begin{array}{l}\text { Pseudomonas fluorescens, }-5 \text { л/га }+\quad 0,1 \% \text { p- } \mathrm{H} \\
\text { ксимедона }+2 \text { мл ДМАЕ }+2 \text { мл ДМSO }\end{array}$ & 3,10 & 3,06 & 2,98 \\
\hline $\begin{array}{l}\text { Pseudomonas fluorescens, }-5 \text { л/га }+0,1 \% \text { p-р ксимедона } \\
+0,2 \% \text { p-p янтарной кислоты }+2 \text { мл ДМАЕ }+2 \text { мл } \\
\text { ДМSO }\end{array}$ & 3,06 & 3,4 & 2,97 \\
\hline
\end{tabular}

При анализе фунгицидной эффективности исследуемых комплексов, отмеченные колебания данного показателя для различных веществ что обусловлено разной эффективностью взаимодействия компонентов. Лучший результат в эффективности против фитофтороза показало сочетание планриз, 5 л/га $+0,1 \%$ раствор ксимедону $+0,2 \%$ раствор янтарной кислоты +2 мл ДМАЭ +2 мл ДМSO, что составляло 79,1\% эффективности препарата.

\section{Выводы}

Внесения производных группы аммонийных солей дигидропиримидина и других исследуемых стимулирующих веществ незначительновлияло на концентрацию жизнеспособных клеток бактерий Pseudomonas fluorescens в приготовленных продуктах 
и не приводили к снижению их концентрации ниже нормы. Максимальный стимулирующий и фунгицидный эффект, при использовании на картофеле и сое, показало применение комплекса планриз, 5 л/га $+0,1 \%$ раствор ксимедону $+0,2 \%$ раствор янтарной кислоты +2 мл ДМАЭ + 2 мл ДМSO. Использование ДМАЭ и ДМSO как веществ, что имеют влияние на различные трансмембранные функции обеспечило увеличение эффективности препаратов.

\section{Библиография}

1. Акимова Е. Е. Влияние бактерий Pseudomonas sp. B-6798 на фитопатологическое состояние картофеля в поле / Е. Е. Акимова // Вестник Томского государственного университета. - 2009. - № 2. - С. 42-47.

2. Березина Н. В. Биопрепараты. Система эффективного применения для защиты овощных культур. / Н. В. Березина, В. Н. Уваров // Вестник овощевода. - 2009. - № 2. C. 49-51.

3. Вязовая А. А. Биологические свойства Pseudomonas fluorescens 2137 и их эффективность на растениях огурца / А. А. Вязовая, Е. В. Лимещенко, Е. С. Купцова, В. М. Бурень // Биологическая защита растений - основа стабилизации агроэкосистем: Мат докл. междунар. науч.-практ. конф. - Краснодар. - 2004. - Вып. 3. - С. 181-183.

4. Горбунов О. П. Совершенствование препаратов на основе Pseudomonas aureofaciens / О. П. Горбунов // Защита и карантин растений. - 2011. - № 5. - С. 35-36.

5. Доспехов Б. А. Методика полевого опыта. / Доспехов Б. А. - М.: Агропромиздат, 1985. - 416 с.

6. Курдиш I. К. Перспективи і проблеми інтродукції мікробних препаратів у агроценози / І. К. Курдиш, Л. С. Церковняк // Наук. вісн. Чернівец. ун-ту. Біологія. 2005. - Вип. 252. - С. 126-131.

7. Патент України на корисну модель № 33738 від 10.07.2008p. Спосіб одержання 5-ароїл-3,6-діарилдигідропіримідин-2,4-1Н,3Н)-діонів / Вовк М.В., Сукач В.А., Кушнір О.В.// Офіційний бюлетень. Промислова власність. Бюл.№9.

8. Патент України на корисну модель № 48943 від 12.04.2010p. Спосіб одержання 1,6-діоксо-8-арил-1,3,4,6,6,7,8-гексагідро-2 Н-піразино $\quad$ (1,2-с)-піримідин-9карбоксилатів / Вовк М.В., Кушнір О.В.// Офіційний бюлетень. Промислова власність. Бюл.№7.

9. Syntesis and oxidant activity of 2-thioxo-1.2.3.4-tetrahipyrimidine-5-carbamides / O.V. Kushnir. O.N. Voloshchuk. R.I. Eften'eva. M.M. Marchenko, M.V. Vovk / Pharm. Chem. J. - 2014. -V.48, №4. - P.246-248). 